\title{
EDITORIAL
}

\section{DEVELOPMENT OF THE DEFENCE SYSTEM}

In the beginning of the year when we were inviting authors to write articles, we were aware that some novelties in the field of security could be anticipated, but were unable to visualize them specifically. Every time we talk about security, defence and the military, we like to mention the global world and constant changes and, consequently use the term transformation almost self-evidently. This term should concisely explain all the complexities of the modern world in this field, but this is not exactly the case. Norfolk, USA, is the base of the Allied Command Transformation whose mission includes education, training and exercises, development of new concepts, and promotion of interoperability among member states. In NATO member states, there are NATO Centres of Excellence for various domains, and each member state has its own military educational institutions and faculties intended for the development of security-related topics, as well as various "think-tank" institutions.

The Slovenian Armed Forces (SAF), or better, the General Staff, which publishes the Contemporary Military Challenges, wishes to contribute to the development of security-related topics in the Republic of Slovenia, especially in the field of defence. According to the Defence Act, the Minister determines military professional literature such as doctrines, instructions, methods and criteria for measuring the level of acquired knowledge and skills, textbooks and periodicals.

SAF organisational units responsible for the development of military professional literature are the following: J-5 (development and international cooperation), J-7 (military training) and Military Schools Centre (development of military textbooks, manuals and lecture notes).

The Slovenian Armed Forces, the Ministry of Defence and the Republic of Slovenia form an integral part of the international security environment. It is right that we provide for a quality development of our defence system so that, if needed, we will 
be able to help others in the international environment. We need a quality defence system in order to be safe at home. The Contemporary Military Challenges is thus one of the excellent opportunities to present our knowledge, ideas and thoughts about the development of Slovenian defence system. Why do we refer to the defence system and not a military one? Because one cannot do without the other. This issue is something special. Only "soldiers" took up our invitation to write an article. Is this a coincidence?

Alojz Steiner wrote an article titled "For better understanding of transformational paradigm and transformation of the armed forces", which presents the various terms denoting the phenomena used in the last few decades in relation to the changes in the defence and military fields. The author derives his findings from the fact that these phenomena have been changing since the end of the Cold War. In different professional and scientific sources, and defence and military practice they have been depicted with a variety of terms that may be synonyms to describe the same phenomena, but are often used to describe completely different ones, which appear quite similar at first. In his article, the author thus provides an explanation in this matter.

In his article titled "Ineffectiveness of the military as an indicator of inappropriate civilian control (1)" Branimir Furlan wonders whether civilian control supports or hinders the military in attaining the efficiency necessary to achieve its mission. He promises a continuation of the article, but already in this one, offers an analytical model that enables the identification of causal link between the control and efficiency. But how do we measure the effectiveness of the military? The author has developed his own definition.

»Role of combined arms warfare in hybrid warfare environment in the context of SAF's current situation and developmental opportunities « is the title theme of Viktor Potočnik, who claims that the concept of hybrid warfare does not entail major revolutionary changes in the forms and methods of warfare, and that the concept of combined arms warfare is still very relevant for winning a modern conflict. However, it must be understood in the context of a contemporary battlefield, whose main features are cyber warfare and "hybridity". Is hybridity a new phenomenon and what exactly is it?

One of the important areas for the development of the defence system is also the area of human capital management discussed by Milan Žurman in his article "Logistics support of the Slovenian Armed Forces in relation to the efficient human capital management system". He notes that the ambitions and needs of users in the Slovenian Armed Forces to provide modern logistics support do not diminish, but remain at the same level or even increase. This has an impact on the human capital management. In the article, the author shares his findings and proposals. 
Marjan Zupančič, Karmen Poklukar and Rafael Kolbl are the authors of the article titled "NATO Mountain Warfare Centre of Excellence - challenges, opportunities and interests". They represent the new international mountain warfare organization accredited on the Slovenian territory. They use the definition by Blaznik that Centres of Excellence are aimed for the transformation of allied forces, increase and improvement of specific capacities, but mostly for a more efficient use of the already developed capabilities of NATO and partner states. In addition, they provide a detailed description of the challenges, opportunities and interests, as promised in the title.

We look forward to your contributions. 